\title{
Comparison of Water Quality Status of Disturbed and Undisturbed Mangrove Forest at Awat-Awat Lawas Sarawak
}

\author{
Seca Gandaseca ${ }^{*}$, Nur Liyana Abd Wahab ${ }^{2}$, Ahmad Mustapha Mohamad Pazi1, \\ Noraini Rosli ${ }^{2}$, Pakhriazad Hassan $\mathbf{Z a k i}^{3}$ \\ ${ }^{1}$ Department of Forest Production, Faculty of Forestry, Universiti Putra Malaysia, Serdang, Malaysia \\ ${ }^{2}$ Faculty of Agriculture and Food Sciences, Universiti Putra Malaysia Bintulu Sarawak Campus, Bintulu, Malaysia \\ ${ }^{3}$ Department of Forest Management, Faculty of Forestry, Universiti Putra Malaysia, Serdang, Malaysia \\ Email: *seca@upm.edu.my
}

Received 15 November 2015; accepted 18 December 2015; published 21 December 2015

Copyright (C) 2016 by authors and Scientific Research Publishing Inc.

This work is licensed under the Creative Commons Attribution International License (CC BY). http://creativecommons.org/licenses/by/4.0/

c) (i) Open Access

\begin{abstract}
Water quality testing was compulsory for management of safe and reliable water sources. Various sources of pollution and destruction of mangrove forest decrease the quality of river water. Thus a study was conducted to determine the water quality status of mangrove forest river water of Awat-Awat Lawas Sarawak and compare the water quality status of disturbed and undisturbed mangrove forest river in that area. Samples from twelve sampling stations were collected from both mangrove forest river from October 2013 to March 2014. In-situ data collected (pH, temperature, dissolved oxygen (DO), salinity, turbidity, total dissolved solid (TDS), conductivity) and laboratory analysis (biochemical oxygen demand (BOD), chemical oxygen demand (COD), ammoniacal nitrogen (AN), total suspended solid (TSS)) were conducted according to the Standard method of Examination of Water and Wastewater AHPA 2005. Six water parameters: pH, DO, BOD, COD, AN and TSS value were used in calculating the Water Quality Index (WQI). Mean values for disturbed area were follows, $\mathrm{pH}(7.07)$, temperature $\left(29.93^{\circ} \mathrm{C}\right)$, salinity $(15.64 \mathrm{PSU})$, turbidity (55.13 NTU), DO (4.59 mg/L), BOD (0.73 mg/L), COD (10.16 mg/L), AN (0.14 mg/L), TSS (53.92 $\mathrm{mg} / \mathrm{L})$, TDS $(23.14 \mathrm{mg} / \mathrm{L})$ and conductivity $(2.61 \mathrm{~ms} / \mathrm{m})$. Undisturbed area results were, $\mathrm{pH}(6.84)$, temperature $\left(28.32^{\circ} \mathrm{C}\right)$, salinity (14.65 PSU), turbidity (35.41 NTU), DO (2.39 mg/L), BOD (0.55 $\mathrm{mg} / \mathrm{L})$, COD (15.82 mg/L), AN (0.13 mg/L), TSS (53.23 mg/L), TDS (22.82 mg/L) and conductivity $(2.34 \mathrm{~ms} / \mathrm{m})$. There were no significant differences between two locations except for DO. Both water qualities of disturbed and undisturbed mangrove forest river were found under Class III, which describe that the water bodies are in moderate quality status.
\end{abstract}

${ }^{*}$ Corresponding author.

How to cite this paper: Gandaseca, S., Wahab, N.L.A., Pazi, A.M.M., Rosli, N. and Zaki, P.H. (2016). Comparison of Water Quality Status of Disturbed and Undisturbed Mangrove Forest at Awat-Awat Lawas Sarawak. Open Journal of Forestry, 6, 14-18. http://dx.doi.org/10.4236/ojf.2016.61002 


\section{Keywords}

\section{Water Quality Index (WQI), Mangrove Forest, Sarawak Malaysia, Disturbed, Undisturbed}

\section{Introduction}

Poor water quality is harmful to living organism and water ecosystem. According to Winter et al. (1998), the interaction of ground water and surface water was affected by human activities and natural process may cause unfavorable aquatic environment. Murty and Kumar (2011) stated that water can load pollution naturally without decreasing in quality. However overflow of pollutant as it reaches its maximum capacity is dangerous to living organism. Mangrove forest shows decreasing in biodiversity result from mangrove forest ecosystems disturbance (Hauff et al., 2006). Due to the increasing rate of human population, the exploration of mangrove forest through human activities such as logging activities, deforestation, agricultural land, and waste from industry gives negative impact to the environment and also to water quality of mangrove forest (Hauff et al., 2006; Smith, 1992; Lugo \& Snedaker, 1974). According to Picket and White (1985) in Gurvich et al., 2005, disturbance is "any relatively several events in time that disrupts ecosystem, community or population structure and change resources, substrate availability or the physical environment”; while undisturbed mangrove forest can be defined as the natural forest without any implementation and exploration of human activities that hold original high density of population.

\section{Materials and Methods}

\subsection{Study Area}

Figure 1 shows the location of study area at Awat-Awat Mangrove Forest Lawas Sarawak, Malaysia. All water samples were taken at two location of mangrove forest river at latitude $4^{\circ} 56^{\prime} \mathrm{N}$ and longitude $115^{\circ} 14^{\prime} \mathrm{E}$ (Figure 1). Lawas is located in Limbang Division in North of Sarawak and experienced an annual rainfall more than $4000 \mathrm{~mm}$ during year. The study area was divided into 2 areas which are disturbed and undisturbed areas.

\subsection{Sampling Methods}

Twelve stations at each location were selected at Awat-Awat Mangrove Forest River. The water samples were

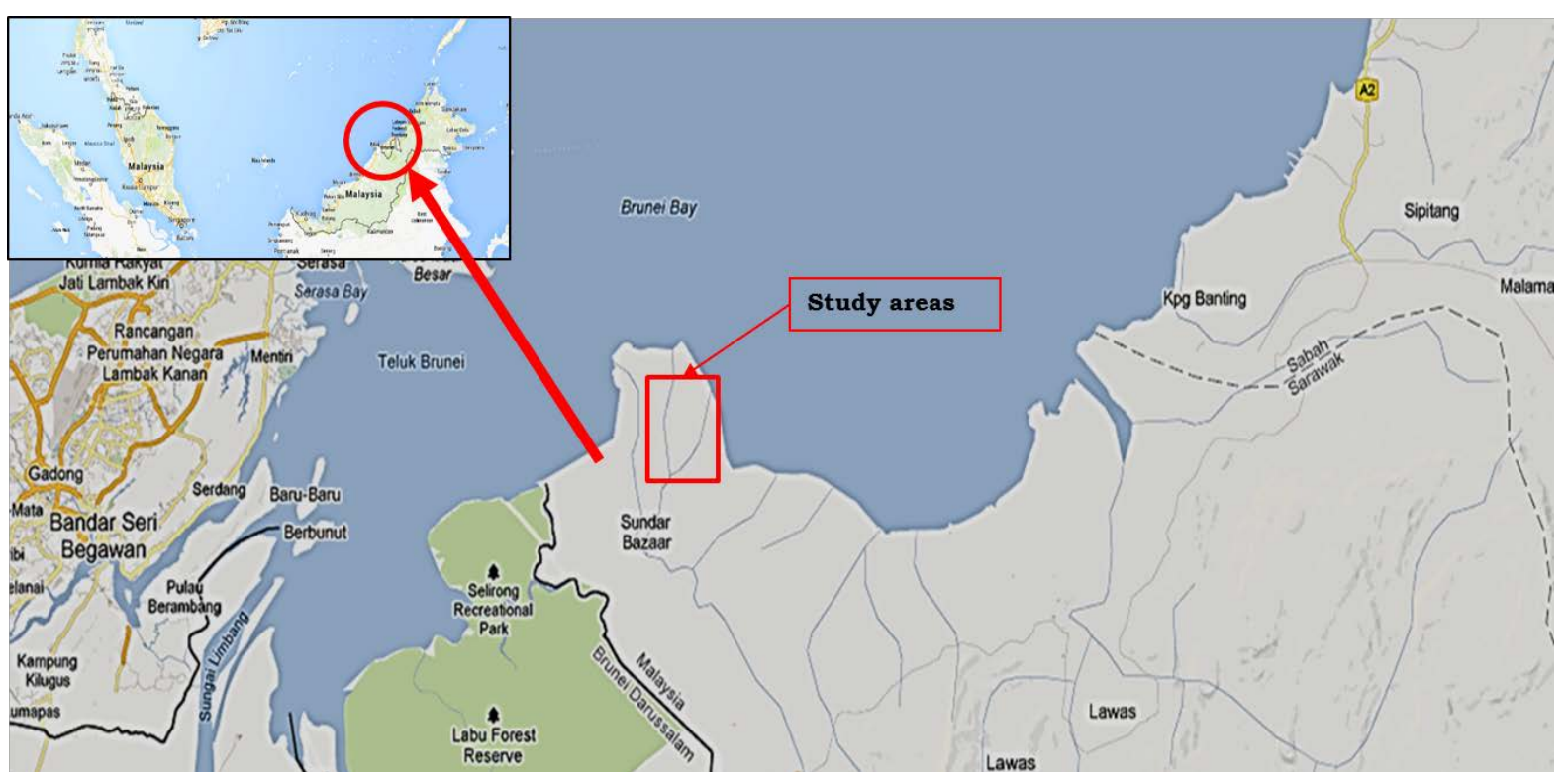

Figure 1. Location of study areas at Awat-Awat Mangrove Forest Lawas Sarawak, Malaysia. 
taken from upstream to downstream in 2013. In-situ data will be taken using in-situ equipment, Water Quality Meter (model WQC-24). Water samples were taken in three replications on each station for laboratory test. The Global Positioning System (GPS) were used to determine the actual coordinates of the sampling stations and to re-confirm the location of the stations during subsequent sampling periods. Water sample from the surface were collected in sampling bottle after rinse with the same water 3 to 4 times. Water samples were collected $10 \mathrm{~cm}$ from surface waters at each sampling station using HDPE (500 mL) and BOD bottles (Gupta, 2009). Standard procedures were followed for water samples collection and water samples analysis done according to Standard Methods APHA 1060 B and C (APHA, 2005; Amadi et al., 2010).

\subsection{Water Quality Analysis}

Water quality data were collected based on in-situ measurements and laboratory analysis. The most common parameters measured are temperature, $\mathrm{pH}$, Dissolved Oxygen, Turbidity. Laboratory analyses are performed to determine biochemical oxygen demand (BOD), chemical oxygen demand (COD), Ammonia and total suspended solids (TSS) level of the water samples. The sample preservation and analytical procedure were followed the Standard Methods (APHA, 1995).

In-situ water quality parameters were analyzed using Water Quality Meter (model WQC-24) consist of temperature, $\mathrm{pH}$, dissolved oxygen (DO), conductivity and turbidity, while another four water quality parameters ammoniacal nitrogen (NH3-N), biochemical oxygen demand (BOD), chemical oxygen demand (COD), alkalinity and total suspended solids (TSS) were analyzed in laboratory according to Standard Methods for the Examination of Water and Wastewater APHA (2005).

\subsection{Data Analysis}

The obtained data were analyzed using Statistical Analysis System (SAS) version 9.2. Comparison of mean for each parameter and mean comparison between stations be done by using Analysis of Variance (ANOVA).

\subsection{Water Quality Index}

The WQI water status are obtained by calculate using calculation of WQI based on DOE, 2011. WQI formula involve the mean of six major parameter value which are DO, BOD, COD, TSS, Ammoniacal Nitrogen and pH. The formula as shown below.

$$
\mathrm{WQI}=(0.22 \times \mathrm{SIDO})+(0.19 \times \mathrm{SOBOD})+(0.16 \times \mathrm{SICOD})+(0.15 \times \mathrm{SIAN})+(0.16 \times \mathrm{SISS})+(0.12 \times \mathrm{SIpH})
$$

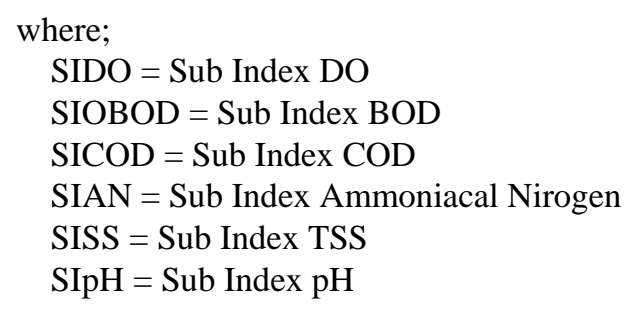

\section{Results and Discussion}

Average water quality status for disturbed and undisturbed mangrove forest river water were in Class III (Table 1). Thus the water tides and other factors give impact to the water quality parameter fluctuation (Pawar, 2013). Temperature values were within the acceptable value for a survival of aquatic organism (Lawson, 2011). Where mean for both area were $29.03^{\circ} \mathrm{C}$ (disturbed) and $28.32^{\circ} \mathrm{C}$ (undisturbed). Six water quality parameters level for disturbed and undisturbed give no different except for DO. Ruttner (1953, cited by Ramanathan et al., 1998) state that the $\mathrm{pH}$ value of water may increase due to the mixing of estuaries water generally average $\mathrm{pH}$ of 7.0 7.5 with sea water that have pH mainly in range 8.1 - 8.3 (Edzwald \& Haarhoff, 2011).

According to Pawar (2013) on his research on water quality of mangrove ecosystem of Uran, Navi Mumbai, and salinity of river water is slightly high during high tides of water as seawater flow into the river and mixed the fresh water. Salt is a particle that has electrolytes that hold negative and positive charge. The higher the salinity the higher the conductivity of the river water. Dissolved Oxygen level of mangrove forest river water were 
below the favourable condition $(5.0 \mathrm{mg} / \mathrm{L}$ ) for aquatic life to survive and it limited for some aquatic species only (Table 2). Lower level of dissolved oxygen due to high number of litter fall and organic matter in the water bodies water (Patnaik, 2005). According to statistical analysis, the comparison mean for each parameter showed there is no significant difference among the parameters except for DO between disturbed and undisturbed mangrove forest river.

In the research Class II ammonia level were recorded, with mean value $0.14 \mathrm{mg} / \mathrm{L}$ and $0.13 \mathrm{mg} / \mathrm{L}$ for disturbed and undisturbed mangrove forest river water respectively. Polluted water with ammonia concentration 2.7 $\mathrm{mg} / \mathrm{l}$ and above were very toxic and dangerous to living organisms (Noraini, 2010; DOE 2009). Mean from the study for $\mathrm{pH}, \mathrm{BOD}, \mathrm{COD}$ and $\mathrm{AN}$ were below the maximum level and classified as acceptable amount to the water.

\section{Conclusion}

Water quality status of disturbed and undisturbed mangrove forest river water was classified under Class III which is in moderate water quality status of water, and there is no significant difference among the parameters except for DO. There are many factors that influence the fluctuation or river water quality. The increasing of development and opening area of plantation near the water bodies may contribute to worse water quality level. Maintaining the mangrove forest environment is important in sustaining the ecosystem and balancing it.

\section{Acknowledgements}

This research is supported by Universiti Putra Malaysia through the Research University Grant Scheme (RUGS). Sincerely thanks to Forest Department of Lawas Sarawak staff for their help and kind cooperation. Thanks go to

Table 1. WQI and class water of Awat-Awat mangrove forest, Lawas Sarawak.

\begin{tabular}{|c|c|c|c|c|c|c|c|c|}
\hline \multirow{2}{*}{ Locations } & \multicolumn{6}{|c|}{ Water Quality Parameters } & \multirow{2}{*}{ WQI } & \multirow{2}{*}{ CLASS } \\
\hline & SIpH & SIDO & SIBOD & SICOD & SIAN & SISS & & \\
\hline Disturbed & 99 & 0 & 97 & 86 & 86 & 70 & 67 & III \\
\hline Undisturbed & 99 & 0 & 98 & 78 & 87 & 71 & 68 & III \\
\hline
\end{tabular}

SIpH $=$ Sub Index pH. SIDO = Sub Index Dissolved Oxygen. SIBOD = Sub Index Biochemical Oxygen Demand. SICOD $=$ Sub Index Chemical Oxygen Demand. SIAN = Sub Index Ammoniacal Nitrogen. SISS = Sub Index Total Suspended Solid.

Table 2. Water quality parameters at Awat-Awat mangrove forest, Lawas Sarawak.

\begin{tabular}{|c|c|c|c|c|c|c|c|c|c|c|c|}
\hline \multirow{2}{*}{ 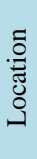 } & \multicolumn{11}{|c|}{ Water Quality Parameters } \\
\hline & $\mathrm{pH}$ & $\begin{array}{c}\text { TEMP } \\
\left({ }^{\circ} \mathrm{C}\right)\end{array}$ & $\begin{array}{c}\text { SAL } \\
\text { (PSU) }\end{array}$ & $\begin{array}{c}\text { TUR } \\
\text { (NTU) }\end{array}$ & $\begin{array}{c}\mathrm{DO} \\
(\mathrm{mg} / \mathrm{L})\end{array}$ & $\begin{array}{c}\text { BOD } \\
(\mathrm{mg} / \mathrm{L})\end{array}$ & $\begin{array}{c}\text { COD } \\
(\mathrm{mg} / \mathrm{L})\end{array}$ & $\begin{array}{c}\mathrm{AN} \\
(\mathrm{mg} / \mathrm{L})\end{array}$ & $\begin{array}{c}\text { TSS } \\
(\mathrm{mg} / \mathrm{L})\end{array}$ & $\begin{array}{c}\text { TDS } \\
(\mathrm{mg} / \mathrm{L})\end{array}$ & $\begin{array}{l}\text { COND } \\
(\mathrm{ms} / \mathrm{m})\end{array}$ \\
\hline 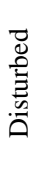 & $\begin{array}{l}0 \\
0 \\
0 \\
0 \\
+1 \\
+\tilde{O} \\
0 \\
0\end{array}$ & 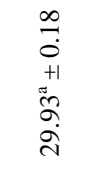 & 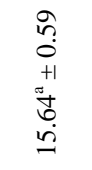 & 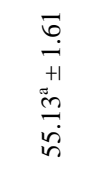 & 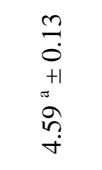 & 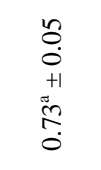 & $\begin{array}{l}\stackrel{+}{\sim} \\
0 \\
+1 \\
+0 \\
0 \\
\vdots \\
0\end{array}$ & 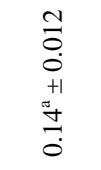 & $\begin{array}{l}\text { N } \\
\text { ஸ் } \\
+1 \\
\tilde{N} \\
\tilde{\sigma} \\
\tilde{n}\end{array}$ & $\begin{array}{l}\stackrel{M}{+} \\
\underset{+1}{+1} \\
\stackrel{\sigma}{ \pm} \\
\stackrel{\sigma}{\sim}\end{array}$ & 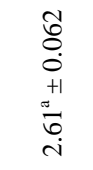 \\
\hline 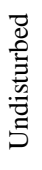 & 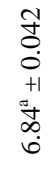 & $\begin{array}{l}\exists \\
\exists \\
0 \\
+1 \\
\tilde{\sigma} \\
\tilde{N} \\
\tilde{\omega} \\
\stackrel{\sim}{N}\end{array}$ & $\begin{array}{l}0 \\
+ \\
0 \\
+1 \\
0 \\
0 \\
0 \\
\dot{I} \\
ت\end{array}$ & 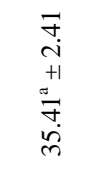 & 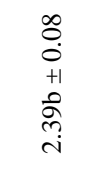 & 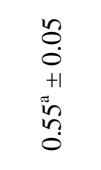 & 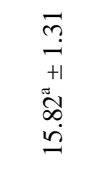 & 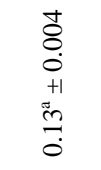 & 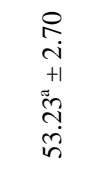 & 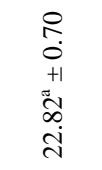 & 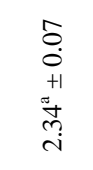 \\
\hline
\end{tabular}

${ }^{*} \pm$ represent standard error of the mean. Means with the same letter are not significantly different at $\mathrm{p}>0.05$. TEMP $(\mathrm{OC})=$ Temperature. SAL $(\mathrm{PSU})=$ Salinity. TUR $(\mathrm{NTU})=$ Turbidity. DO $(\mathrm{mg} / \mathrm{L})=$ Dissolved Oxygen. BOD $(\mathrm{mg} / \mathrm{L})=$ Biochemical Oxygen Demand. COD $(\mathrm{mg} / \mathrm{L})=$ Chemical Oxygen Demand. AN $(\mathrm{mg} / \mathrm{L})=$ Ammoniacal Nitrogen. TSS $(\mathrm{mg} / \mathrm{L})=$ Total Suspended Solid. TDS $(\mathrm{mg} / \mathrm{L})=$ Total Dissolved Solid. 
Universiti Putra Malaysia Bintulu Sarawak Campus staff for help.

\section{References}

Amadi, A. N., Olasehinde, P. I., Okosun, E. A., \& Yisa, J. (2010). Assessment of the Water Quality Index of Otamiri and Oramiriukwa Rivers. Physics International, 1, 116-123.

APHA, \& World Education Fellowship (WEF) (1995/1998). Standard Methods for the Examination of Water and Wastewater, 20.

APHA (American Public Health Association) (2005). Standard Methods for the Examination of Water and Wastewater (21st ed.). Washington, DC: American Public Health Association.

DOE (Department of Environment) (2009). Water Quality (River) Monitoring System/Programme and Pollution Control. Hashim Daud (Director, Water and Marine Division). Ministry of Natural Resources and Environment.

Edzwald, J. K., \& Haarhoff, J. (2011). Seawater Pretreatment for Reverse Osmosis: Chemistry, Contaminats and Coagulation. Water Research, 45, 5428-5440. http://dx.doi.org/10.1016/j.watres.2011.08.014

Gupta, P. K. (2009). Methods in Environmental Analysis: Water, Soil and Air (p. 433). India: Agrobios.

Gurvich, D. E., Tecco, P. A., \& Díaz, S. (2005). Plant Invasions in Undisturbed Ecosystems: The Triggering Attribute Approach. Journal of Vegetation Science, 16, 723-728. http://dx.doi.org/10.1111/j.1654-1103.2005.tb02415.x

Hauff, R. D., Ewel, K. C., \& Jack, J. (2006). Tracking Human Disturbance in Mangrove: Estimating Harvest Rates on a Micronesian Island. Wetland Ecology and Management, 14, 95-105. http://dx.doi.org/10.1007/s11273-005-2567-y

Lawson, E. O. (2011). Physico-Chemical Parameters and Heavy Metal Contents of Water from the Mangrove Swamps of Lagos Lagoon, Lagos, Nigeria. Advance in Biological Research, 5, 8-21.

Lugo, A. E., \& Snedaker, S. C. (1974). The Ecology of Mangroves. Annual Review of Ecology and Systematics, 5, 39-64. http://dx.doi.org/10.1146/annurev.es.05.110174.000351

Murty, M. N., \& Kumar, S. (2011). Water Pollution in Indian. Economic Appraisal, Indian Infrastructure Report.

Noraini, R., Seca, G., Johan, I., \& Iqbal, M. J. (2010). Comparative Study of Water Quality at Different Peat Swamp Forest at Batang Igan, Sibu Sarawak. American Journal of Environ Science, 6, 416-421. http://dx.doi.org/10.3844/ajessp.2010.416.421

Patnaik, K. N. (2005). Study of Environmental Pollution of major industries in Paradip Area. Ph.D. Thesis, Bhubneshwar: Utkal Universiti.

Pawar, P. R. (2013). Monitoring of Impact of Anthropogenic Inputs on Water Quality of Mangrove Ecosystem of Uran, Navi Mumbai, West Coast of India. Marine Pollution Bulletin, 75, 291-300. http://dx.doi.org/10.1016/j.marpolbul.2013.06.045

Ramanathan, A. L., Subramanian, V., Ramesh, R., Chidambaram, S., \& James, A. (1998). Environmental Geochemistry of the Pichavaram Mangrove Ecosystem (Tropical), Southeast Coast of India. Environmental Geology, 37, $223-233$. http://dx.doi.org/10.1007/s002540050380

Smith, T. J. (1992). Forest Structure. In A. I. Reberston, \& O. M. Alongi (Eds.), Tropical Mangrove Ecosystem (pp. 101136). Washington, DC: American Geophysical Union. http://dx.doi.org/10.1029/CE041p0101

Winter, T. C., Harvey, J. W., Franke, O. L., \& Alley, N. M. (1998). Ground Water and Surface Water. U.S. Geologist Survey. 